\title{
Horizontal Imbalances of Russian Federation Budget System
}

\author{
Sabitova N. M. ${ }^{1}$, Shavaleyeva C. M. ${ }^{1} \&$ Nikonova E. N. ${ }^{1}$ \\ ${ }^{1}$ Kazan Federal University, Institute of Management, Economics and Finance, Kazan, 420008, Russia \\ Correspondence: Sabitova N. M., Kazan Federal University, Institute of Management, Economics and Finance, \\ Kazan, 420008, Russia. Tel: 7-903-388-9599. E-mail: sabitovanm@mail.ru
}

Received: March 10, 2015 Accepted: March 31, 2015 Online Published: April 30, 2015

doi:10.5539/ass.v11n11p248 URL: http://dx.doi.org/10.5539/ass.v11n11p248

\begin{abstract}
The Russian Federation constituents differ not only in size and population but also in economic potential and, as a consequence, in the financial abilities to apply their budget authorities. The result is that the RF budget system features imbalances that are regulated at the federal level through equalisation transfer. This is associated with such principles of the RF budget system as unity and equality of budget laws. This paper describes the case study of horizontal imbalance of the RF budget system being a result of economic disparity of the regions: the fiscal equalisation mechanism is described and appraised for its efficiency.
\end{abstract}

Keywords: budget system, horizontal imbalance, fiscal equalisation, grants, Russia's regions

\section{Introduction}

The Russian Federation is the largest country in the world, which area is administratively divided in 85 regions, including over 23,000 municipalities. However, the regions significantly differ in their performance. This differentiation is primarily associated with historical allocation of tax base and political, economic and geographic, natural and climatic factors, as well as availability of human capital assets and production infrastructure. As an example, at 3,083.5 thousand square kilometres, the Republic of Sakha (Yakutia) is the largest region of Russia, which area is 856 times the area of the smallest region, the Republic of Ingushetia, with its 3.6 thousand square kilometres. The population of the Nenets Autonomous Okrug is 42.8 thousand inhabitants while 11,979.5 thousand people are Moscow's residents, i.e. 280 times more. There is a significant difference between the Russian Federation constituents in terms of the Gross Regional Product. Particularly, over 35\% of Gross Regional Product is produced in the Central Federal District, including Moscow with 22\% and only $2.4 \%$ in the North Caucasian Federal District, where the share of the Republic of Ingushetia amounts to $0.06 \%$. The difference of the RF constituents in their economic potential has an effect on budgeting and leads to a considerable disparity of their fiscal capacity.

\section{Theory}

The scientific literature gives much attention to the areal disparity of the regions. Among other things, the subject matter and origin of this phenomenon were studied by Arzaghi, M., Henderson, J. V. (2005), Pina-Sánchez, J. (2014), Vo, D. H. (2010). The international experience in finding solution to the problem of fiscal decentralisation is studied in the papers of Reayat, N., Ahmad, I., Khalil, J., Rahim, T. (2014), Bird, R. M., Smart, M. (2002), Sacchi, A., Salotti, S. (2014). The fiscal equalisation through dedicated financial funds is described by Kyriacou, A. P., Roca-Sagalés, O. (2012). The experience of the Russian Federation is analysed by Popov, V. (2001), Desai, R. M., Freinkman, L., Goldberg, I. (2005), Blanchard, O., Shleifer, A. (2001)[10], Jarocińska, E. (2010). However, further studying these issues did not lose edge.

\section{Results}

The RF budget system bases on such principles as unity and equality of budget laws that ensure all RF constituents to receive grants from the federal budget to satisfy fiscal capacity being at a normal level. Every year the Russian Federation Ministry of Finance calculates the Fiscal Capacity Level (FCL) of the RF constituents, based on which the grants are calculated. The fiscal capacity of RF constituents shows, how the consolidated budget expenditures of an RF constituent on rendering equal fiscal services per capita may be ensured by tax revenues of the consolidated budget of such RF constituent, which are determined with due consideration of development level and structure of tax base of such constituent. The calculated fiscal capacity level prior to allocation of grants will be determined by the following formula: 


$$
\mathrm{FCL}=\mathrm{TCI} / \mathrm{BEI},
$$

where

FCL - the calculated fiscal capacity level prior to allocation of grants;

TCI - the taxable capacity index being a relative (as compared with the national average level) assessment of the $\mathrm{RF}$ consolidated budget revenues, which determination is based on development and structure of tax base of an RF constituent;

BEI - the budget expenditure index of an RF constituent being a relative (as compared with the national average level) assessment of the RF consolidated budget spending of such RF constituent on rendering equal fiscal services per capita, which determination is based on unbiased regional factors and conditions.

The analysis of the RF Ministry of Finance data on fiscal capacity level of Russia's regions shows that the FCL vary widely depending on the geography. Figure 1 illustrates the differentiation of RF constituents as part of Federal Districts. The Ural Federal District regions have the highest FCL, the regions of the Northwestern Federal District are far behind being second, the third place is occupied by the regions of the Central Federal District and the Volga Federal District regions hit the fourth position. The fiscal capacity level of the RF constituents of the above listed Federal Districts is higher than the national average. As these Federal Districts includes well-situated regions, it can explain their top position. As for example, the major oil-producing regions of Russia such as Khanty-Mansi Autonomous Okrug, Yamalo-Nenets Autonomous Okrug and Tyumen Region are in the Ural Federal District. Their fiscal capacity is traditionally high (it was 1.89, 2.27 and 2.51 in 2014, while the national average being 1). The Northwestern Federal District consists of such developed regions as Leningrad and Vologda Regions, Republic of Komi and Saint Petersburg, which FCL is above 1 before allocation of grants. The Central Federal District has such economically developed regions as Moscow, the Lipetsk, Yaroslavl and Moscow Regions.

The regions of the North Caucasian Federal District show the lowest FCL being below 0.33 .

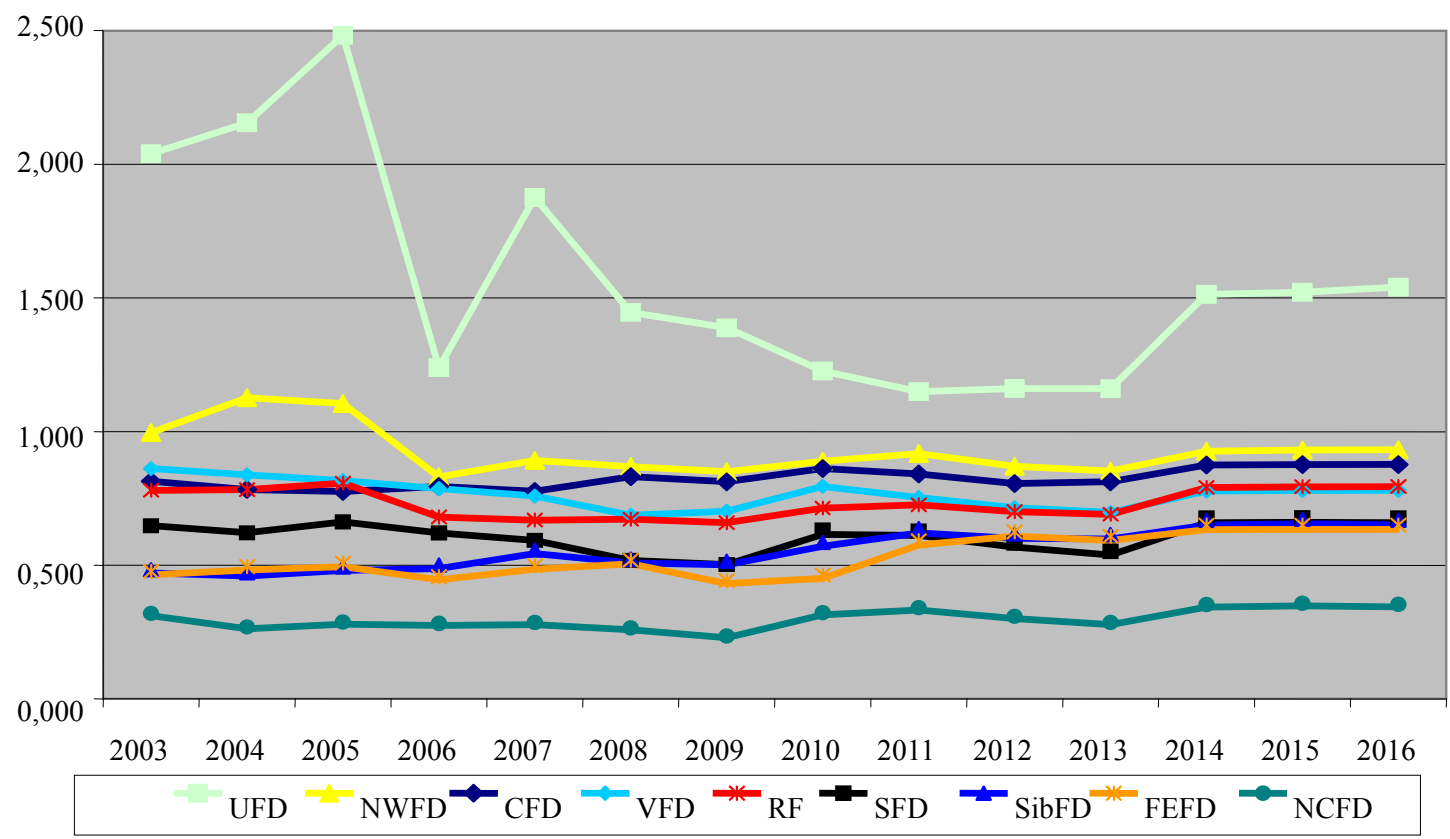

Figure 1. The fiscal capacity level of the RF constituents in terms of federal districts in 2003-2006 (Note 1, 2)

Note 1. Planned targets are shown for 2015-2016.

Note 2. Central Federal District - CFD, Northwestern Federal District - NWFD, Southern Federal District SFD, North Caucasian Federal District - NCFD, Volga Federal District - VFD, Ural Federal District - UFD, Siberian Federal District - SibFD, Far Eastern Federal District - FEFD.

In accordance with the Russian Federation laws, grants being a key equalisation tool are given for no-purpose allocation. The grants are provided to such RF constituents, which calculated FCL does not exceed the level specified as the equalisation criterion. As is seen in Table 1, granting enhances the fiscal capacity of the RF 
constituents. As for instance, the grant allocation in 2013 increased the fiscal capacity of the North Caucasian Federal District regions from 0.278 to 0.573 while the national average jumped from 0.691 to 0.785 .

Analysing the gap in fiscal capacity level between the 10 well-situated and 10 ill-provided regions suggests that the gap was more than 10 times prior to grant allocation over 2003-2008, while it dropped to 6-6.7 times since 2010 (Table 2). After granting, the gap reduced to 3-3.8 times over 2003-2005 and roughly to 2.7 times since 2006. Therefore, the grant-based fiscal equalisation mechanism enables reducing the financial disparity of the RF regions. Moreover, the observance says that the gap in fiscal capacity between well-situated and ill-provided regions is gradually reducing. Thus, if the gap before granting was 15.7 in 2005 , it amounted to only 6.2 times in 2014; and after granting -3.8 and 2.8 times, respectively.

Table 1. The Fiscal Capacity Level of the Federal Districts and the national average FCL in 2005-2013

\begin{tabular}{ccccccccccc}
\hline Federal Districts & FCL & 2005 & 2006 & 2007 & 2008 & 2009 & 2010 & 2011 & 2012 & 2013 \\
\hline \multirow{2}{*}{ CFD } & Before & 0,776 & 0,795 & 0,777 & 0,831 & 0,812 & 0,861 & 0,841 & 0,805 & 0,812 \\
& After & 0,872 & 0,889 & 0,864 & 0,925 & 0,885 & 0,947 & 0,926 & 0,872 & 0,867 \\
NWFD & Before & 1,105 & 0,830 & 0,892 & 0,869 & 0,850 & 0,890 & 0,918 & 0,870 & 0,852 \\
& After & 1,157 & 0,877 & 0,936 & 0,923 & 0,887 & 0,947 & 0,967 & 0,906 & 0,881 \\
\multirow{2}{*}{ SFD } & Before & 0,662 & 0,621 & 0,593 & 0,518 & 0,503 & 0,615 & 0,612 & 0,568 & 0,538 \\
& After & 0,813 & 0,788 & 0,744 & 0,685 & 0,637 & 0,749 & 0,739 & 0,669 & 0,631 \\
NCFD & Before & 0,280 & 0,275 & 0,278 & 0,259 & 0,229 & 0,314 & 0,332 & 0,301 & 0,278 \\
& After & 0,664 & 0,660 & 0,633 & 0,631 & 0,593 & 0,656 & 0,655 & 0,610 & 0,573 \\
VFD & Before & 0,817 & 0,786 & 0,759 & 0,687 & 0,702 & 0,795 & 0,754 & 0,715 & 0,698 \\
& After & 0,935 & 0,910 & 0,871 & 0,801 & 0,764 & 0,864 & 0,830 & 0,782 & 0,759 \\
UFD & Before & 2,482 & 1,239 & 1,876 & 1,445 & 1,388 & 1,227 & 1,149 & 1,161 & 1,161 \\
& After & 2,525 & 1,276 & 1,936 & 1,510 & 1,444 & 1,295 & 1,215 & 1,216 & 1,210 \\
SibFD & Before & 0,481 & 0,488 & 0,544 & 0,509 & 0,502 & 0,571 & 0,621 & 0,601 & 0,599 \\
& After & 0,740 & 0,679 & 0,755 & 0,732 & 0,677 & 0,746 & 0,771 & 0,729 & 0,715 \\
FEFD & Before & 0,495 & 0,445 & 0,485 & 0,506 & 0,431 & 0,451 & 0,576 & 0,609 & 0,593 \\
& After & 0,710 & 0,627 & 0,668 & 0,710 & 0,610 & 0,679 & 0,764 & 0,763 & 0,730 \\
\multirow{2}{*}{ RF } & Before & $\mathbf{0 , 8 0 7}$ & $\mathbf{0 , 6 8 1}$ & $\mathbf{0 , 6 6 9}$ & $\mathbf{0 , 6 7 3}$ & $\mathbf{0 , 6 5 9}$ & $\mathbf{0 , 7 1 4}$ & $\mathbf{0 , 7 2 6}$ & $\mathbf{0 , 7 0 1}$ & $\mathbf{0 , 6 9 1}$ \\
& After & $\mathbf{0 , 9 6 7}$ & $\mathbf{0 , 8 2 5}$ & $\mathbf{0 , 8 4 3}$ & $\mathbf{0 , 8 2 9}$ & $\mathbf{0 , 7 8 5}$ & $\mathbf{0 , 8 4 8}$ & $\mathbf{0 , 8 5 0}$ & $\mathbf{0 , 8 0 6}$ & $\mathbf{0 , 7 8 5}$ \\
\hline
\end{tabular}

Data of RF Ministry of Finance

Table 2. Fiscal equalisation over 2003-2016

\begin{tabular}{lccccccc}
\hline \multicolumn{1}{c}{ FCL } & $\mathbf{2 0 0 3}$ & $\mathbf{2 0 0 4}$ & $\mathbf{2 0 0 5}$ & $\mathbf{2 0 0 6}$ & $\mathbf{2 0 0 7}$ & $\mathbf{2 0 0 8}$ & $\mathbf{2 0 0 9}$ \\
\hline Before granting & 0,781 & 0,783 & 0,807 & 0,681 & 0,669 & 0,673 & 0,659 \\
After granting & 0,984 & 0,962 & 0,967 & 0,825 & 0,843 & 0,829 & 0,785 \\
Gap before granting & 13,9 & 17,7 & 15,7 & 10,1 & 9,9 & 10,3 & 9,1 \\
Gap after granting & 3,1 & 3,7 & 3,8 & 2,7 & 2,9 & 2,7 & 2,8 \\
\hline \multicolumn{1}{c}{ FCL } & $\mathbf{2 0 1 0}$ & $\mathbf{2 0 1 1}$ & $\mathbf{2 0 1 2}$ & $\mathbf{2 0 1 3}$ & $\mathbf{2 0 1 4}$ & $\mathbf{2 0 1 5}$ & $\mathbf{2 0 1 6}$ \\
\hline Before granting & 0,714 & 0,726 & 0,701 & 0,691 & 0,791 & 0,794 & 0,794 \\
After granting & 0,848 & 0,850 & 0,806 & 0,785 & 0,889 & 0,845 & 0,864 \\
Gap before granting & 6,6 & 5,8 & 6,2 & 6,7 & 6,2 & 6,1 & 6,3 \\
Gap after granting & 2,4 & 2,4 & 2,6 & 2,8 & 2,8 & 2,6 & 2,9 \\
\hline
\end{tabular}

Data of RF Ministry of Finance

Figure 2 demonstrates data of Table 2.

However, it should be noted that the existing fiscal equalisation mechanism focuses more on short-term solution to the problem of budget imbalance so that it does not facilitate the socio-economic development of the regions. This is evidenced by data of Table 3 showing that the federal budget highly contributed in 2010-2014 to the same RF constituents: Republic of Sakha (Yakutia), Republic of Dagestan, Kamchatka Territory, Altai Territory, Chechen Republic. The contribution flow increases from year to year. Based on this, it can be assumed that the financial situation in these regions does not improve. They use the funds allocated from the federal budget to cover the current expenditures. Logically to assume that the regional authorities are not interested in developing their regions under such conditions as they receive the funds every year but increase in fiscal capacity will reduce the budget flow. 


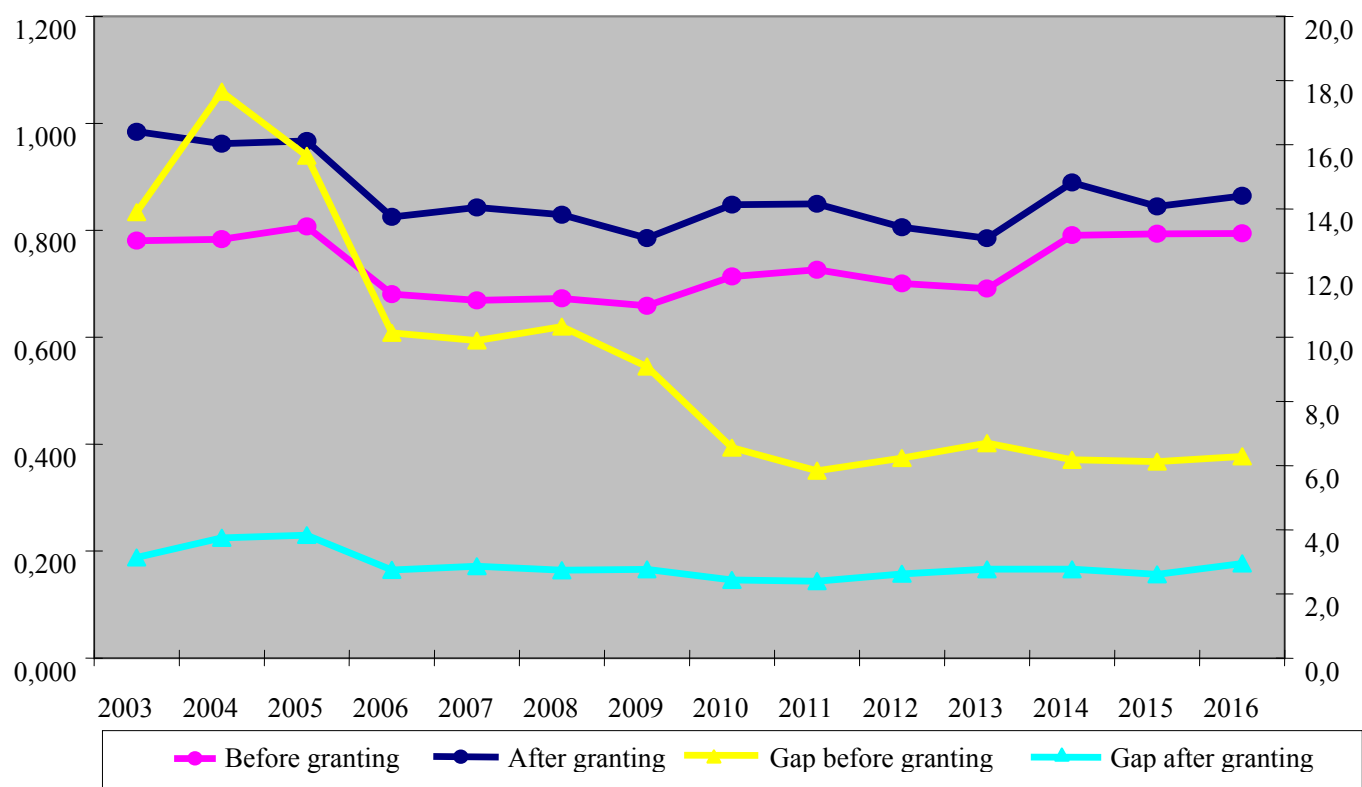

Figure 2. Fiscal equalisation over 2003-2016

Table 3. Grants for fiscal equalisation of the RF constituents in expenditures of federal budget

\begin{tabular}{|c|c|c|c|c|c|c|}
\hline \multirow[b]{2}{*}{ year } & \multirow{2}{*}{$\begin{array}{l}\text { Everything, } \\
\text { million } \\
\text { rubles. } \\
\end{array}$} & \multirow{2}{*}{$\begin{array}{l}\text { Number of the constituents } \\
\text { of the RF which received } \\
\text { this type of grants }\end{array}$} & \multicolumn{4}{|c|}{ Constituents of the RF, which received the greatest sum } \\
\hline & & & \multirow{2}{*}{$\begin{array}{c}\text { Constituents of the RF } \\
\text { Republic of Sakha (Yakutia) }\end{array}$} & \multirow{2}{*}{$\begin{array}{c}\begin{array}{c}\text { sum, one } \\
\text { million rubles }\end{array} \\
39200,91\end{array}$} & \multicolumn{2}{|c|}{$\begin{array}{l}\text { Specific weight in the total } \\
\text { amount of this type of grants }\end{array}$} \\
\hline \multirow{5}{*}{2010} & \multirow{5}{*}{396995,66} & \multirow{5}{*}{70} & & & 9,87 & \multirow{5}{*}{30,54} \\
\hline & & & Republic of Dagestan & 30366,87 & 7,65 & \\
\hline & & & Kamchatka Territory & 22249,70 & 5,60 & \\
\hline & & & Altai Territory & 16402,17 & 4,13 & \\
\hline & & & Chechen Republic & 13067,00 & 3,29 & \\
\hline \multirow{5}{*}{2011} & \multirow{5}{*}{396995,66} & \multirow{5}{*}{69} & Republic of Sakha (Yakutia) & 39771,81 & 10,02 & \multirow{5}{*}{32,92} \\
\hline & & & Republic of Dagestan & 31137,75 & 7,84 & \\
\hline & & & Kamchatka Territory & 29342,24 & 7,39 & \\
\hline & & & Altai Territory & 17178,27 & 4,33 & \\
\hline & & & Chechen Republic & 13278,04 & 3,34 & \\
\hline \multirow{5}{*}{2012} & \multirow{5}{*}{396995,66} & \multirow{5}{*}{72} & Republic of Sakha (Yakutia) & 44896,90 & 11,31 & \multirow{5}{*}{35,90} \\
\hline & & & Republic of Dagestan & 36855,71 & 9,28 & \\
\hline & & & Kamchatka Territory & 29924,16 & 7,54 & \\
\hline & & & Altai Territory & 16343,00 & 4,12 & \\
\hline & & & Chechen Republic & 14507,18 & 3,65 & \\
\hline \multirow{5}{*}{2013} & \multirow{5}{*}{418830,42} & \multirow{5}{*}{73} & Republic of Sakha (Yakutia) & 51357,75 & 12,26 & \multirow{5}{*}{38,58} \\
\hline & & & Republic of Dagestan & 43157,56 & 10,30 & \\
\hline & & & Kamchatka Territory & 31674,11 & 7,56 & \\
\hline & & & Chechen Republic & 17875,78 & 4,27 & \\
\hline & & & Altai Territory & 17541,25 & 4,19 & \\
\hline \multirow{5}{*}{2014} & \multirow{5}{*}{439771,94} & \multirow{5}{*}{72} & Republic of Sakha (Yakutia) & 50714,17 & 11,46 & \multirow{5}{*}{37,18} \\
\hline & & & Republic of Dagestan & 43777,81 & 9,95 & \\
\hline & & & Kamchatka Territory & 33835,30 & 7,69 & \\
\hline & & & Chechen Republic & 19359,16 & 4,40 & \\
\hline & & & Altai Territory & 16196,49 & 3,68 & \\
\hline
\end{tabular}

Based on federal budget laws for a financial period in question as recently amended

Therefore, the analysis shows that the existing mechanism of grant allocation needs to be further enhanced. The grants given to the RF regions should be aimed not only to current budget balance, but also to the total social and economic development. 


\section{Conclusions}

Analysing the budgetary disparity between the RF regions and fiscal equalisation based on grants from the federal budget provides the following conclusions:

1. Over 10 years of studying the FCL revealed that the Russian Federation budget system is still horizontally imbalanced as evidenced by the gap of fiscal capacity before allocation of grants received from the federal budget. This horizontal imbalance has slightly reduced as follows: In 2003-2008, the gap in fiscal capacity level between the 10 well-situated and 10 ill-provided regions of Russia was more than 10 times and 6-7 times since 2010. The Ural Federal District regions have the highest FCL, the regions of the Northwestern Federal District are far behind being second, and the regions of the Central Federal District hit the third place.

2. The existing grant-based mechanism of fiscal equalisation reduces the degree of fiscal capacity of the RF regions. For instance, the gap after granting reduced to 3-3.8 times over 2003-2005 and roughly to 2.7 times since 2006. In this case, the gap in fiscal capacity between well-situated and ill-provided regions is gradually reducing. The activity of the RF Ministry of Finance to equalise the financial situation in the regions may be recognised effective on the basis thereof.

3. Despite the improved fiscal equalisation mechanism, there is a significant disparity in the fiscal capacity of the RF regions, which demonstrates its necessity for enhancement, including reduction in the number of grant-receiving regions and motivation of Russia's regions for economic and financial growth. Oil and gas component of economic and financial potential of the Russian Federation does not focus the regions on development of other trades. In practice, all grant-receiving RF constituents are consumers of oil and gas return as it was over $50 \%$ of the federal budget income before 2014. In the context of fall in oil prices, the situation has changed so that the enhancement of fiscal equalisation mechanism becomes now top urgent.

\section{References}

Arzaghi, M., \& Henderson, J. V. (2005). Why countries are fiscally decentralizing. Journal of Public Economics, 89(7), 1157-1189. http://dx.doi.org/10.1016/j.jpubeco.2003.10.009

Bird, R. M., \& Smart, M. (2002). Intergovernmental fiscal transfers: International lessons for developing countries. World Development, 30(6), 899-912. http://dx.doi.org/10.1016/S0305-750X(02)00016-5

Blanchard, O., \& Shleifer, A. (2001). Federalism with and without political centralization: China versus Russia. IMF Staff Papers, 48, 171-179.

Desai, R. M., Freinkman, L., \& Goldberg, I. (2005). Fiscal federalism in rentier regions: Evidence from Russia. Journal of Comparative Economics, 33(4), 814-834. http://dx.doi.org/10.1016/j.jce.2005.08.004

Jarocińska, E. (2010). Intergovernmental grants in Russia. Economics of Transition, 18(2), 405-427.

Kyriacou, A. P., \& Roca-Sagalés, O. (2012). The impact of EU structural funds on regional disparities within member states. Environment and Planning C: Government and Policy, 30(2), 267-281.

Official website of the Ministry of Finance of the Russian Federation. Retrieved from http://www.minfin.ru

Pina-Sánchez, J. (2014). Decentralization as a multifaceted concept: A more encompassing index using bayesian statistics. Revista Espanola de Ciencia Politica, 1(34), 9-34.

Popov, V. (2001). Reform strategies and economic performance of Russia's regions. World Development, 29(5), 865-886. http://dx.doi.org/10.1016/S0305-750X(01)00006-7

Reayat, N., Ahmad, I., Khalil, J., \& Rahim, T. (2014). Fiscal decentralisation: What does the international experience suggests. Life Science Journal, 11(7), 1-10.

Sacchi, A., \& Salotti, S. (2014). How regional inequality affects fiscal decentralisation: Accounting for the autonomy of subcentral governments. Environment and Planning C: Government and Policy, 32(1), 144-162. http://dx.doi.org/10.1068/c1241r

Vo, D. H. (2010). The economics of fiscal decentralization. Journal of Economic Surveys, 24(4), 657-679.

\section{Copyrights}

Copyright for this article is retained by the author(s), with first publication rights granted to the journal.

This is an open-access article distributed under the terms and conditions of the Creative Commons Attribution license (http://creativecommons.org/licenses/by/3.0/). 